\title{
Teachers' Professional Autonomy in England: are neo-liberal approaches incontestable?
}

\author{
JON BERRY
}

\begin{abstract}
This article is informed by a longitudinal research project undertaken with 22 teachers, four head teachers and two other related education professionals in England between May 2010 and April 2011. Drawing on 50 semi-structured interviews and some related email correspondence, the project investigates this cohort's view of teachers' professional autonomy. It takes as its starting point the hegemony of neoliberal policy and the adoption and reinforcement of this by UK political parties of all persuasions. The outcomes of the project demonstrate that notwithstanding the thrust of such policy - manifested most obviously by the current conversion of increasing numbers of schools to semi-privatised academy status - teachers acknowledge, explicitly or otherwise, the prevalence of performativity and survivalism yet often retain loyalty to the concept of education as a liberal humanist project as opposed to that of a provider of human capital. In short, they manage to cling to a notion of teaching that transcends the demands of the pursuit of measurable standards. They also recognize the central paradox of the current policy ensemble embodied in the inconsistency of rhetoric from government about professional autonomy alongside strong central control and scrutiny. The article goes on to ask whether, given the expressed antipathy on the part of this government and its predecessors towards research informed policy in general, and to qualitative research in particular, it is possible that such voices will be heeded by power. There are clear implications here for teacher education at initial and post-qualification level.
\end{abstract}

Bill Clinton's 1992 US presidential campaign claimed for itself the aphorism that 'it's the economy, stupid.' As European states attempt to navigate their way through their current travails, it is almost facile to observe that if the economy was the central fact of political life in 1992, it is even more so twenty years on. The effect on school and university leavers facing unemployment rates of over $20 \%$ in Greece and Spain, with those in other European countries often in the 
mid-teens in terms of percentage points, is an economic reality that affects educators at all levels. An almost universal discourse around austerity and cuts in spending permeates all aspects of public life, with educational provision frequently identified as an area for scrutiny in this regard. With policy makers committed to neo-liberal solutions, looking to market forces and privatisation to set the terms for provision, what chances remain for a teaching force to retain some vision of education for our children that goes beyond the reductive agenda of results and speciously measured outcomes consistent with such an agenda?

In England this discourse is writ large in the commitment of the coalition government to the expansion of academy schools. Such schools are funded through taxation but free from democratically elected localised control. Corporations, charities, religious foundations and a range of interested parties are encouraged to provide services and facilities with these sponsors entitled to any resultant profits and surpluses. Instigated by New Labour as a measure to, ostensibly, address provision in areas of social disadvantage - albeit that many (Beckett, 2007; Yandell, 2009) saw the move as evidence of a political commitment to a move towards a privatised system - the programme was taken up with alacrity by the newly installed UK government in May, 2010. Pressing the legislation through parliamentary procedure with speed unprecedented even in terms of anti-terrorism measures (Academies Act, 2010) financial incentives were put in place to make the move towards academy status and away from local government control almost irresistible. At the time of writing, it is estimated (Department for Education [DfE], 2012) that over half of England's secondary schools have applied for academy status or are in the process of doing so. The Secretary of State for Education has instigated moves to force some schools down this route; ever-expanding franchised chains (Miller, 2011) run schools in various parts of the country and head teachers in such schools have been able to enjoy salary increases far in excess of their counterparts in non-academy schools (Shepherd, 2011). The vigour and energy invested in the project by the new government has been instrumental in sending the clearest message to teachers about its commitment to this privatised model of provision.

The rhetoric of the government is interesting (DfE, 2010). Using the language of freedom and equality of opportunity it promises freedom from bureaucracy and unnecessary government intrusion; above all, it talks of liberating schools and teachers from curricular constraints, allowing them to teach as they see fit. Simultaneously, however, it is unwavering in its commitment to a regime of national age-related testing in a limited number of subjects and equally as committed to continuing the current practice of placing the outcomes from such tests into the public domain. The use of the synthetic phonics approach to reading is posited as a central feature on which schools will be inspected - again, for outcomes to be publishable - and the measure by which league tables of the results for 16-year-olds will be formulated has been narrowed to five or six of the most traditional subject areas. In a further development, those schools deemed to be outstanding in terms of the inspection 
system run by the Office for Standards in Education, recognised ubiquitously as Ofsted, will be free from any further inspection for the foreseeable future. As a policy whose professed purpose is the liberation of a hitherto constrained and restricted workforce, what we have here is a set of preconditions that establish indicators for recognised success that have profound implications for both teachers and the institutions in which they operate. The paradox suggested by this rhetoric is clearly captured in the heavily ironic observations of one of the respondents in my study. This senior teacher remarks that while government says that 'teachers are free to teach what they want in their own direction, unfortunately the direction's already set in stone and therefore you have to just arrive at the destination that somebody else has made for you.'

This fundamental paradox, born of the rhetoric of freedom juxtaposed to measures that are, in practice, coercive, inform the comments of many respondents. In effect, such responses are, of themselves, a recognition of a central feature of neo-liberal policy as it affects most aspects of political and economic life, but of education in particular: for neo-liberal policies, which promote freedom through market forces and privatisation, to flourish, the state has to establish the conditions for this to happen (Harvey, 2005; Harris, 2007; Hill, 2009). This uneven balance between the illusion of freedom and the reality of coercion is reflected in the discourse around teacher autonomy of the last four decades. At base, I would argue that commentary about workers' autonomy in general has its roots in Braverman's (1974) analysis that in a world in which managerialism holds sway, such autonomy is, at best, characterised by limited decision making from a narrowly fixed range of choices. In educational terms, Dale (1989) characterised this as a move from licensed to regulated autonomy following the most direct intervention the state had ever made in England in the form of the Education Reform Act (ERA) of 1988. From here Ball (1990) among others, and after Foucault and Gramsci, conceptualised the introduction of a controlled autonomy via the logic of industrial production and, critically, the co-option of teachers into a system of self-discipline. Around the turn of the century, a notion of teacher autonomy emerges that is both directed and coercive, with Ofsted and league tables playing a major part in such coercion (Jeffrey \& Woods, 1996; Bottery \& Wright, 2000; Furlong et al, 2000; Quicke, 2000). This incremental movement towards a restricted autonomy has produced an autonomy that is earned - an oxymoronic concept (Bates, 2009) - and characterised variously as prescribed and coercive with, crucially, the promise of reward held out for the complaint (Evans, 2007; Whitty, 2007; Beck, 2009; Storey, 2009). These various theoretical positions, all of which have resonance with the cultural and professional practice of teachers, underwrite the situation where it becomes possible for a government to vaunt the possibilities of freedom while maintaining a firm and directional hand over how teachers go about their professional duties.

This diminution of teacher autonomy is bound up with a reductive view of curriculum and pedagogy consistent with the demands of market ideology that requires the production of identifiable and measurable outcomes. Notions 
of the education of the whole child, notwithstanding apparently laudable projects such as No Child Left Behind (USA) or Every Child Matters (UK), are subsumed when it becomes imperative for schools to demonstrate success judged against an increasingly narrow set of criteria. It was as early as 1981 that Simon identified an unwillingness of the part of the English education system to engage with pedagogy in any serious way and other commentators (Alexander, 2004, 2010; Apple, 2004) have developed this line of argument since. A discourse of effectiveness, 'best practice' and above all 'what works' has created a hegemonic situation where the promotion of practices that are auditable and compliant with current policy initiatives take precedence. When underpinned by notions informed by New Public Management (NPM) (Ferlie et al, 1996; Hood, 1995 ) along with those of performativity and survivalism (Ball, 2008) the space for inventiveness, experimentation and, indeed, autonomous decision making by teachers, becomes increasingly closed down.

Scrutiny of the language and detail of policy in England as evinced by the raft of legislation introduced by the coalition government after May, 2010 is instructive in this regard. The centrality of the move towards academy status and the telling speed with which measures to enable this were implemented has already been acknowledged - but the importance of this measure cannot be overstated. The improvements envisaged through these reforms, although never articulated in any detailed way, will all flow, we are told, through conversion to academy status which will 'devolve as much power as possible to the front line' and liberate schools from bureaucratic burdens through 'a streamlined and effective accountability system.' The Act does not concern itself with curriculum, teachers or students but places great emphasis on managerial and organisational arrangements along with over 27 references to the transferring of fiscal duties and responsibilities for the transfer of property from local government bodies. The concurrent legislation which lays out the new government's vision for education (DfE, 2010) is equally revealing. A foreword from the Prime Minister locates the importance of education as the driver that will enable the nation to keep pace with international competitors: 'that is what will define our economic growth and our country's future.' In a document which purports to centralize the importance of teaching, there is no reference to theoretical understanding, curriculum or pedagogy, but the facility for head teachers to exercise flexibility over pay and to offer other financial incentives is mentioned on twelve occasions. School league tables are to be reformed in order to 'put far more information into the public domain' - how the collection and collation of such enhanced information sits with a promise to reduce bureaucracy is not explained - and there are repeated references to concentration on 'basics' and 'core subjects' with no recognition that both such concepts may be contestable. Underpinning such reforms is a commitment to 'restore' firm classroom discipline (a narrative of lost golden ageism typifies much of the documentation) with the introduction of a scheme to encourage former members of the military forces to become teachers as a central feature of this. 
When one turns to plans for the training - the term is preferred to education - of new teachers (DfE, 2011), this discourse of the primacy of market forces, alongside a disregard for theoretical understanding in favour of plain common-sense, is writ large. The measures proposed cannot be disaggregated from a prevalent narrative around value for money, accountability and measurability underwritten by a topically all-pervasive societal discourse around the requirement to cut public expenditure. The need to make better investment' predominates in much of the document in which, in an expression of (one imagines) unintended banality, the need to provide training that 'is more effective in preparing trainees to be successful in the classroom' is the expressed intention. The document promotes the efficacy of a scheme (Teach First) that recruits highly qualified graduates with no former teaching experience or any formal training, reminds the reader of the need to keep pace with international competitors and restates the central importance of the use of synthetic phonics and the need to maintain orderly behaviour. Once again, the structural changes embodied in the Academies Act are seen as the instrument which will enable progress to be made on these fronts along with the recruitment and retention of a stronger teaching force, notwithstanding a recognition of the fact that 'we have in our schools today the best generation of teacher we have ever had.' This already strong professional body will be enhanced by a recruitment process that will become more rigorous and thorough and will be 'incentivised' by such measures as targeted training bursaries and a more open market to allow an expanded range of 'high quality providers into the system.' Further to this, training providers will need to put their employability record in to the public domain as 'an incentive to encourage better retention rates.' In a further indication of the lack of importance attributed to theoretical and pedagogical understanding the term 'pedagogy' is not used at any point in the document. The only mention of theory is to observe that 'there is some evidence that university-based trainees see their training as too theoretical.' Alongside this a number of financial measures are proposed to make it easier for schools to become involved with training, albeit with an acknowledgement that universities may have some part to play in the process. Principal among the financial arrangements would be an increase in some funding to allow trainees to 'take on more teaching responsibilities as they are training' in an attempt to make the employment of such trainees attractive to schools.

Against such a background, with such an array of forces cementing the hegemony of neo-liberal policy and the pre-eminence of the market, what chance does the teacher have of retaining any utopian vision (Hammersley, 2008) or one that goes beyond the techno-rationalist approach to teaching (Bottery \& Wright, 2000) that fits so well with the demands of such a system? Ball (1999) conceptualised a teacher's soul in jeopardy, bound and captured by a regime of control and measurement to which teachers themselves both acquiesced and consented through an element of self-discipline. In a small-scale piece of research with 13 teachers, each with over fifteen years' of experience, conducted in December 2011, this somewhat pessimistic view was reinforced, 
with 12 responses indicating agreement that those new to teaching did little to question the demands of the current system. Many comments expressed a view that teachers new to the profession, themselves the objects as students of a highly regulated, results-driven system, were constrained, in the words of a head teacher of twenty years' standing, by the fact that 'it is all they have known so they don't imagine it can be different.' As a teacher educator, I frequently witness how much of the verve, energy and imagination of those new to the profession contracts in the face of formulaic, systems-led lessons that, literally, tick boxes on observation sheets or, just as frequently, have more regard for the minutiae of examination and test requirements than anything approaching an understanding of the subject matter in hand. Is it the case, then, this reductive and constrained experience of teaching and learning, notwithstanding power's rhetoric of freedom, holds sway? And if so, what are the implications for both the education and continuing professional development of teachers?

In May, 2010, partly because of exasperation at having witnessed a succession of dull and mechanical lessons conducted by training teachers, I embarked upon an investigation into teachers' views of their professional autonomy. The study was given extra, contemporary relevance by the fact that it began just as the new government began to moot the measures referred to above. A cohort of 22 serving teachers, none of whom were head teachers and all of whom, in a factor that is undoubtedly germane to the study, had made a commitment to study as part of on-going professional development, participated in two rounds of semi-structured interviews and engaged in some email correspondence over the following seven months. As an initially unplanned part of this research project, the findings from this cohort were put to some head teachers and two other interested parties in the Spring of 2011. The principal outcomes from the communication with the 22 teachers are outlined below, grouped into two broad categories with the first showing a degree of satisfaction with a level of managed autonomy and the second outlining dissatisfaction with a range of factors that impact upon such autonomy.

\section{Broad Satisfaction}

- The interviews show that these teachers unequivocally embrace the concept of professional responsibility with willingness and do not contest the need to be accountable to those around them, including senior management, parents and, above all, their own students.

- All but two teachers interviewed acknowledge that it is possible for them to enjoy some degree of professional autonomy, albeit entirely contingent on their producing the outcomes - almost always in the form of test results required by their institution.

- The role of head teachers is seen as crucial for the promotion of any professional autonomy and those interviewed largely felt supported by their own Heads. 
- On a localised, school-based level, these teachers largely felt that they enjoyed a degree of trust, albeit that a regime of inspection, both formal and informal, was sometimes felt to infract such trust.

\section{Dissatisfaction}

- The constant drive to demonstrate student progress in an overt way is a widespread complaint and one that elicits annoyance and frustration from these teachers. This complaint is extensive and prevalent in teachers' responses.

- There is dissatisfaction with a degree of sophistry, occasionally descending into dishonesty, which can occur as a corollary to this quest for results and their eventual release into the public domain.

- There is dissatisfaction that too much time is spent generating results for the collation of data at the expense of pursuing ideas that could enhance enjoyment and learning.

- The degree of trust enjoyed at a localised, school-based level is in direct, stark contrast to teachers' views about their relationship with central government, towards whom an overwhelming sense of mistrust is directed. This mistrust is not based on party political allegiance.

- Such mistrust stems from what is seen as the paradox of rhetoric about freedom being propounded simultaneously with a commitment to regulation, inspection and the release of information - seen by professionals as questionable - into the public domain.

- This mistrust is compounded by suspicion that such rhetoric about freedom is seen as organisational and managerial but not as 'freedom to teach'.

- The centrality of an inspection regime - Ofsted - and a continuing commitment to it in its inspectoral, as opposed to an advisory, role is seen as a further contributory factor to this mistrust.

- There is a very strong sense among these teachers that they could offer their students more were they to feel confident about breaking with the requirements of the current standards' agenda.

Many of these findings are unsurprising to a professional working in the field. The drive to produce results, to maintain a public profile that celebrates success in these terms and to subjugate one's preferred approaches in an effort to do so are the stuff of many casual conversations with teachers. (As an aside, I was approached by a number of teachers who were not part of the chosen cohort who, having heard about the study, were eager to furnish me with evidence, information and a range of related anecdotes.) The extent to which any autonomy enjoyed by these teachers is constrained by the need to produce acceptable outcomes is entirely consistent with the developing characterisations of different forms of autonomy referred to by commentators above. The dichotomy of a perception of trust at a local, institutional level that is not mirrored by a trust endowed by a remote, central government appears to be a 
reflection of the efforts of school managers to mitigate, where possible, some of the most intrusive effects of a centrally set agenda. The level of 'gaming' acknowledged even in government documentation - in order to achieve successful national test results is now sutured deeply into the culture of many schools. The ubiquity of such attitudes, values and actions does not, of course, make them any the more acceptable, but they are the facts of life in many English schools. Were these the sole outcomes of the study we could be forgiven for lapsing into deep pessimism: fortunately they are not.

The final bullet point in the summary of findings above relates to the idea that teachers feel that there is more they could offer were they not constrained by the apparatus of measurability. The strength of feeling in this matter resounds in the comments of respondents in this study. A science teacher talks of her determination to introduce her students to the importance of the Hadron Collider despite its absence on any recognised examination syllabus; a maths teacher pursues her interest in the Enigma code breaker even though she feels she may have 'wasted' a lesson doing so; a primary teacher talks of the excitement of studying the Aztecs before the school is 'turned into a sort of boot camp' before the national tests begin; another primary teacher relates his insistence on exciting his class's imagination with the story of trapped Chilean miners even though this is a departure from the agreed scheme of work. Such instances abound in the comments of teachers; if their collective soul is, indeed, in jeopardy, then the fact that three other teachers in this cohort specifically invoke the spirit of teaching portrayed in the film Dead Poets' Society as their preferred model would seem to indicate that it has not yet been irrevocably damned.

Teachers are clear that their professional autonomy is restricted by the downward pressure exerted upon them stemming from governmental decisions and, from there, filtered through the managerial actions of schools leaders. In an interesting strain of response, some teachers are fully aware of the constraints under which such leaders operate. Only one respondent, however, chooses to locate the provenance of this apparatus of control as a function of wider political and economic choices and imperatives. In a fascinating development of these notions of autonomy, some, but not all, head teachers to whom the findings were put were less convinced that this loss of autonomy was necessarily burdensome or unwelcome. One talks of the need to buy into the culture of achievement' and bemoans individualism that could infract this. He goes on to criticise unnecessary 'angst' on the part of teachers and in this view he is joined by a head teacher colleague who believes that teachers are much 'freer than they think.' Another, while advocating the desirability of teachers who can excite and enliven by going 'off-piste', tempers her comments by remarking that 'not many teachers can do that' successfully. Overall, what consolidates the views of these school leaders is that while there may well be room for a leading cadre to experiment and explore, a default and conformist offer must be in place for the rest. One could argue, as does one of these Heads along with another respondent from this cohort, that this default position ensures a basic 
entitlement for all children; it is not an argument without merit. The counter argument is that in a system driven by the market, in which parental choice, howsoever uneven (Whitty, 1997), is a key driver, and where some schools benefit from the recruitment of a disproportionate number of academically able students, this results in a situation where certain schools, and teachers, are liberated to be creative and expansive while others exist on more meagre and reductive fare. This potential reward for the already successful, or for the compliant, is reinforced by new legislation in England that promises an exemption from inspection for those schools who receive the best ratings when judged against current criteria. In another instructive comment from one of the head teachers, he suggests that this inspectoral body (Ofsted) should revel in its status as a feared organisation - a sentiment echoed in more temperate terms by two others, albeit not subscribed to by all.

What is revealed from these data is that despite the plethora of forces that act upon the individual teacher - and I would argue that these forces originate at the level at which nation states espouse a neo-liberal approach to social and economic policy which, in turn, work their way eventually into the classroom of the individual teacher - a notion of education that has not foregone adherence to liberal humanism endures. The teachers in this study know and understand that there is more that could - and, in their view, should - be offered to young people. The central question arises: does power care? And if, as will be argued, it does not, what, then, are the implications for teacher education and teachers' professional development?

Educational researchers using qualitative methods in England should be under no illusions: such research is largely inimical to the purpose and direction of the current government and, indeed, many of its predecessors. Many critics draw a correspondence between this governmental mistrust and what they see as the substandard nature of some of this research (Furlong \& Oancea, 2006; Lawn \& Furlong, 2009). Others advocate a more focused and realistic approach to such research, suggesting that keeping a closer eye on power's priorities would be prudent (Demerritt, 2000). Others still (Hammersley, 2008) regret the abandonment of epistemological independence seen as implicit in such a stance: a position with which I concur. The preference of power for research that is bound up with the production of better measurable outcomes - the sort of research favoured in a range of policy areas beyond education - is clear (House, 2005; Silverman, 2006). We return here to the prevalent notion of what works', identified above in relation to discussion of curricula but which runs as a clear strain through government thinking - and most markedly in its proposals for teacher education discussed above. Even allowing for the citing of sources to substantiate the claim that school based training is a proven and successful method that is somewhat cavalier (Berry, 2012), these proposals are embodied in a document (DfE, 2011) in which the term 'pedagogy' is not used at any point. The only mention of theory is to observe that there is some evidence that university-based trainees see their training as too theoretical.' The message from such policy seems to be clear and, pertinently, in tune with those 
head teachers who seek success, recognition or, it could be argued, the wherewithal to survive in competitive times: the promulgation of predetermined outcomes has become incontestable.

Is this an irredeemably miserable picture? I would argue not for a number of reasons. First, teachers themselves continue to cling to a notion of something better to offer as the results of this study demonstrate. Although largely compliant and acquiescent on a day-to-day basis, there is residual idealism and an appreciation of some of the forces at work upon them. Second, strong academic voices (Hargreaves \& Shirley, 2009) continue to promote notions of 'real' teaching, even seeing the possibility of some gaps in the policy ensemble into which teachers can begin to insert their own vision and imagination. Moreover, there is an acceptance even in the rhetoric of the new legislation which acknowledges a degree of damage that can be inflicted by overprescriptive systems - always assuming that we are prepared to shelve concerns about the paradox of central control coexisting with talk of freedoms. Beyond all of these matters pertaining to the control of education, a societal discourse of resistance that has begun to question the dominance of the market and, even, for the first time in some decades in the west, the very efficacy of capitalism itself (Eagleton, 2011) has had the effect of opening arguments deemed by some to have been buried by history.

The concluding remarks here go to one of the study's respondents. A senior teacher with some 30 years' experience, he finds himself in a school that has been earmarked for closure by local government as part of a regional restructuring. As student numbers diminish and the school contracts, the leadership team, of which he is part, decide to take advantage of the situation to encourage a more experimental and creative approach by teaching staff. Most are happy to go along with this and enjoy this new-found freedom. The school generally becomes more relaxed as 'the black cloud' of inspection and general scrutiny assumes decreasing importance in their foreshortened existence. He talks of 'taking more risks - more chances' and of the way in which, in a reversal of the usual regime of classroom observation, this is looked for by senior staff. In an unanticipated, but not wholly surprising development as far as this teacher is concerned, the results in all public tests and examinations improve. In terms of robust, controlled research this single episode proves nothing. What it does do, however, is to provide resonance for those respondents who suspect that if left to exercise a greater degree of autonomy, the results of their students would not suffer and a more fulfilling experience could be enjoyed by all parties. At present, the luxury of such freedom cannot be enjoyed by all. If teachers and those who educate them and develop their professional practice are to extend the reach of this freedom, it becomes vital for us to understand the neo-liberal model of social policy has to be challenged in all of its manifestations. 


\section{References}

Academies Act (2010)

http://www.legislation.gov.uk/ukpga/2010/32/contents/data.htm

Alexander, R. (2004) Still no Pedagogy? Principle, Pragmatism and Compliance in Primary Education, Cambridge Journal of Education, 34(1), 7-33.

http://dx.doi.org/10.1080/0305764042000183106

Alexander, R. (2010) Legacies, Policies and Prospects: one year on from the Cambridge Primary Review. The Brian Simon Memorial Lecture.

http://www.primaryreview.org.uk/downloads/publications/public_lectures/Simo n_lecture_text.pdf

Apple, M. (2004) Ideology and Curriculum. London: Routledge.

Ball S. (Ed.) (1990) Foucault and Education: disciplines and knowledge. London: Routledge.

Ball, S. (1999) Global Trends in Educational Reform and the Struggle for the Soul of the Teacher! Paper presented at the British Educational Research Association Annual Conference, 2-5 September. http://www.leeds.ac.uk/educol/documents/00001212.htm

Ball, S. (2008) The Great Education Debate. London: Policy Press.

Bates, A. (2009) The Paradox of Earned Trust: bringing professional trust and autonomy out of the shadow of New Labour's remodelling of the teaching professions. Discourse Power and Resistance Conference, Greenwich, April, unpublished.

Beck, J. (2009) Appropriating Professionalism: restructuring the official knowledge base of England's 'modernised' teaching profession, British Journal of Sociology of Education, 30(1), 3-14. http://dx.doi.org/10.1080/01425690802514268

Beckett, F. (2007) The Great City Academy Fraud. London: Continuum.

Berry, J. (2012) An Investigation into Teachers' Professional Autonomy in England: implications for policy and practice. Unpublished $\mathrm{PhD}$ thesis.

Bottery, M. \& Wright, N. (2000) The Directed Profession: teachers and the state in the third millennium, Journal of In-Service Education, 26(3), 475-487.

http://dx.doi.org/10.1080/13674580000200141

Braverman, H. (1974) Labor (sic) and Monopoly Capital. London: Monthly Review Press.

Dale, R. (1989) The State and Education Policy. Buckingham: Open University Press.

Demeritt, D. (2000) The New Social Contract for Science: accountability, relevance and value in US and UK science and research policy, Antipode, 32(3), 308-329. http:/ /dx.doi.org/10.1111/1467-8330.00137

Department for Education (DfE) (2010) The Importance of Teaching - The Schools White Paper http://www.education.gov.uk/publications/standard/publicationdetail/page1/C M\%207980

Department for Education (DfE) (2011) Training our Next Generation of Outstanding Teachers. http://media.education.gov.uk/assets/files/pdf/t/training\%20our\%20next\%20ge neration\%20of\%20outstanding\%20teachers.pdf 
Department for Education (DfE) (2012) Open Academies and Academy Projects in Development.

http://www.education.gov.uk/schools/leadership/typesofschools/academies/b00 208569/open-academies

Eagleton, T. (2011) Why Marx was Right. New Haven, CT: Yale University Press.

Evans, L. (2007) Professionalism, Professionality and the Development of Educational Professionals, British Journal of Educational Studies, 56(1), 20-38. http://dx.doi.org/10.1111/j.1467-8527.2007.00392.x

Ferlie, E., Ashburner, L., Fitzgerald, L. \& Pettigrew, A. (1996) The New Public Management in Action. Oxford: Oxford University Press. http://dx.doi.org/10.1093/acprof:oso/9780198289029.001.0001

Furlong J., Whitty, G., Whiting, C., Miles, L. \& Barton, L. (2000) Teacher Education in Transition: re-forming professionalism? Buckingham: Open University Press.

Furlong, J. \& Oancea, A. (2006) Accessing Quality in Applied and Practice Based Research in Education: a framework for discussion, Review of Australian Research in Education: counterpoints on the quality and impact of educational research, 6, 89-104. http://www.bera.ac.uk/pdfs/Qualitycriteria.pdf

Hammersley, M. (2008) Troubling Criteria: a critical commentary on Furlong \& Oancea's framework for assessing educational research, British Educational Research Journal, 34(6), 747-762. http://dx.doi.org/10.1080/01411920802031468

Hargreaves, A. \& Shirley, D. (2009) The Fourth Way: the inspiring future for educational change. London: Sage.

Harris, S. (2007) The Governance of Education: how neo-liberalism is transforming policy and practice. London: Continuum.

Harvey, D. (2005) A Brief History of Neo-liberalism. Oxford: Oxford University Press.

Hill, D. (Ed.) (2009) Contesting Neo-liberal Education. Oxford: Routledge.

Hood, C. (1995) The 'New Public Management' in the 1980s: variations on a theme, Accountings, Organisation and Society, 2(3), 93-109. http://dx.doi.org/10.1016/0361-3682(93)E0001-W

House, E. (2005) Qualitative Evaluation and Changing Social Policy, in N. Denzin \& Y. Lincoln (Eds) The Sage Handbook of Qualitative Research. London: Sage.

Jeffrey, B. \& Woods, P. (1996) Feeling Deprofessionalised: the social construction of emotions during an Ofsted inspection, Cambridge Journal of Education, 26(3), 325-343. http://dx.doi.org/10.1080/0305764960260303

Lawn, M. \& Furlong, J. (2009) The Disciplines of Education in the UK: between the ghost and the shadow, Oxford Review of Education, 35(5), 541-552. http://dx.doi.org/10.1080/03054980903216283

Miller, F. (2011) Are Profit-making Chains the Future for Academies?, The Guardian. http://www.guardian.co.uk/education/2011/jul/04/profit-making-academies

Quicke, J. (2000) A New Professionalism for a Collaborative Culture of Organisational Learning in a Contemporary Society, Educational Management and Administration, 28(3), 299-315.

Shepherd, J. (2011) Academies Pay £200k Salaries, The Guardian. http://www.guardian.co.uk/education/2011/nov/14/academies-pay-200ksalaries?CMP $=$ twt_gu 
Silverman, D. (2006) Interpreting Qualitative Data. London: Sage.

Simon, B. (1981) Why No Pedagogy in England? Education in the Eighties, in B. Moon \& A. Shelton Mayes (1994) Teaching and Learning in the Secondary School. Buckingham: Open University Press.

Storey, A. (2009) How Fares the 'New Professionalism' in Schools? Findings from the 'State of the Nation' Project, Curriculum Journal, 20(2), 121-138. http://dx.doi.org/10.1080/09585170902948806

Whitty, G. (1997) Creating Quasi-markets in Education: a review of recent research on parental choice and school autonomy in three countries, Review of Research in Education, 22, 3-47.

Whitty, G. (2007) Teacher Professionalism in New Times, Journal of In-Service Education, 26(2), 281-295. http://dx.doi.org/10.1080/13674580000200137

Yandell, J. (2009) Lighthouses or Follies? Academies and New Labour's Version of History, Changing English, 16(2), 125-135. http://dx.doi.org/10.1080/13586840902863111

Correspondence: j.berry@herts.ac.uk 
